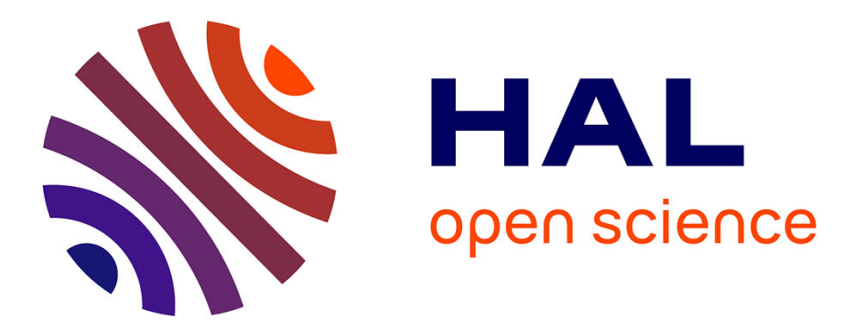

\title{
Impact of feeding by Arenicola marina (L.) and ageing of faecal material on fatty acid distribution and bacterial community structure in marine sediments: An experimental approach
}

Vincent Grossi, Philippe Cuny, Sarah Caradec, David Nerini, Richard

Pancost, Franck Gilbert

\section{To cite this version:}

Vincent Grossi, Philippe Cuny, Sarah Caradec, David Nerini, Richard Pancost, et al.. Impact of feeding by Arenicola marina (L.) and ageing of faecal material on fatty acid distribution and bacterial community structure in marine sediments: An experimental approach. Journal of Experimental Marine Biology and Ecology, 2006, 336, pp.54-64. 10.1016/j.jembe.2006.04.003 . hal-00148497

\author{
HAL Id: hal-00148497 \\ https://hal.science/hal-00148497
}

Submitted on 21 May 2013

HAL is a multi-disciplinary open access archive for the deposit and dissemination of scientific research documents, whether they are published or not. The documents may come from teaching and research institutions in France or abroad, or from public or private research centers.
L'archive ouverte pluridisciplinaire HAL, est destinée au dépôt et à la diffusion de documents scientifiques de niveau recherche, publiés ou non, émanant des établissements d'enseignement et de recherche français ou étrangers, des laboratoires publics ou privés. 


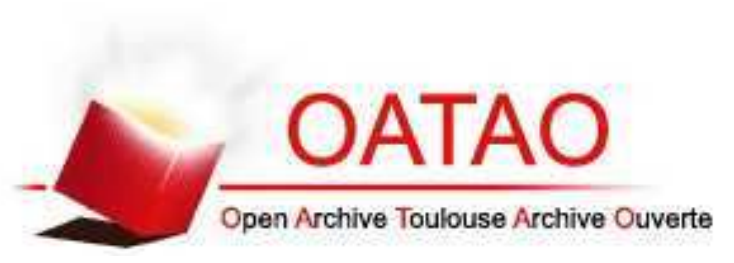

\section{Open Archive Toulouse Archive Ouverte (OATAO)}

OATAO is an open access repository that collects the work of Toulouse researchers and makes it freely available over the web where possible.

This is an author-deposited version published in: http://oatao.univ-toulouse.fr/ Eprints ID: 6095

To link to this article: DOI: $10.1016 /$ j.jembe.2006.04.003 URL: http://dx.doi.org/10.1016/j.jembe.2006.04.003

To cite this version: Grossi, Vincent and Cuny, Philippe and Caradec, Sarah and Nerini, David and Pancost, Richard and Gilbert, Franck Impact of feeding by Arenicola marina (L.) and ageing of faecal material on fatty acid distribution and bacterial community structure in marine sediments: An experimental approach. (2006) Journal of Experimental Marine Biology and Ecology, vol. 336 ( ${ }^{\circ}$ 1). pp. 54-64. ISSN 0022-0981

Any correspondence concerning this service should be sent to the repository administrator: staff-oatao@ listes.diff.inp-toulouse.fr 


\title{
Impact of feeding by Arenicola marina (L.) and ageing of faecal material on fatty acid distribution and bacterial community structure in marine sediments: An experimental approach
}

\author{
Vincent Grossi ${ }^{\mathrm{a}, *}$, Philippe Cuny ${ }^{\mathrm{a}}$, Sarah Caradec ${ }^{\mathrm{a}, \mathrm{b}, 1}$, David Nerini ${ }^{\mathrm{a}}$, \\ Richard Pancost ${ }^{b}$, Franck Gilbert ${ }^{\mathrm{a}}$ \\ a Laboratoire de Microbiologie, Géochimie et Ecologie Marines - UMR CNRS 6117, Centre d'Océanologie de Marseille (OSU), \\ Université de la Méditerranée, Campus de Luminy - Case 901, 13288 Marseille Cedex 9, France \\ ${ }^{\mathrm{b}}$ Organic Geochemistry Unit, Biogeochemistry Research Centre, School of Chemistry, University of Bristol, Cantock's Close, \\ Bristol, BS8 1TS, United Kingdom
}

\begin{abstract}
The fate of ingested eukaryotic photoautotrophic fatty acids during gut transit in the lugworm Arenicola marina (L.) and the influence of A. marina's faeces on the evolution of fatty acid distribution and bacterial community structure in superficial sediments were studied under laboratory conditions. Dead phytoplanktonic cells (food portions) were fed to individual A. marina and subsequently incubated, or allowed to directly incubate in the presence of fresh egesta or non-ingested sediment. Changes in fatty acid composition and genetic structure of bacterial communities during gut transit and/or incubation were monitored using gas-chromatography/mass-spectrometry and a DNA fingerprint approach (RISA), respectively. Results, supported by principal component analyses, suggest that $A$. marina's feeding activity can directly and indirectly affect the lipid biomarker composition and the bacterial community structure of inhabited sediments. Faecal casts produced from food portions appeared qualitatively enriched in saturated fatty acids relative to (poly)unsaturated ones due, partly, to an increase of some bacterial fatty acids and to the preferential removal of some polyunsaturated fatty acids (PUFAs). The incubation of food portions in the presence of fresh $A$. marina's egesta (designed to study the indirect impact of feeding by $A$. marina) induced a significant increase in the concentrations of $\mathrm{C}_{20}$ and $\mathrm{C}_{22}$ polyunsaturated fatty acids (PUFAs), whereas these compounds almost disappeared following direct feeding and subsequent incubation, indicating that some dietary fatty acids may be more accessible to biodegradation following passage through the gut of $A$. marina. The aforementioned increase in PUFAs was attributed to a bacterial production during incubation, suggesting the presence of PUFA-producing bacteria in the fresh egesta of $A$. marina. Those bacteria were either enteric bacteria that were released with the egesta or ingested bacteria that have survived gut passage, as suggested by the variations of the bacterial community structure (i.e. RISA profiles) during incubation. The results suggest that aged faeces from $A$. marina might be, in some circumstances, of relatively high nutritional value to trophic levels which are unable to synthesize essential PUFAs de novo. The presence of PUFA-producing bacteria in guts of marine lugworms deserves further attention.
\end{abstract}

Keywords: Arenicola marina; Feeding activity; Fatty acids; PUFA-producing bacteria; Bacterial community structure; RISA; Superficial sediments

\footnotetext{
* Corresponding author. Present address: Paléoenvironnements et Paléobiosphère - UMR CNRS 5125, Université Claude Bernard Lyon 1 , Campus de la Doua - Bâtiment Géode, 69622 Villeurbanne Cedex, France. Tel.: +33 472445 813; fax: +33 472431688.

E-mail address: vincent.grossi@univ-lyon1.fr (V. Grossi).

${ }^{1}$ Present address: Laboratoire de Chimie des Eaux, Service d'analyses et de caractérisation, 16 route de Gray, 25030 Besançon Cedex, France.
} 


\section{Introduction}

Benthic macrofauna have a significant impact on the biogeochemical processes in marine sediments, through activities such as particle reworking, irrigation, feeding and bacterial gardening/stimulation (Banta et al., 1999; Aller et al., 2001). To meet their nutritional needs, deposit feeders ingest massive volumes of sediment by bulk feeding, and extract organic matter (OM) from different food sources such as digestible detritus (e.g. phytoplanktonic remains), microbes and benthic microbiota (Lopez and Levinton, 1987; Andresen and Kristensen, 2002). As a result of the ingestion process, marine worms produce faeces which can represent a potential food source for other consumers and be the site of intense geochemical transformation of OM (Wilde and Plante, 2002; Plante and Wilde, 2004).

Feeding by deposit-feeders can significantly affect the qualitative and quantitative distribution of specific components of OM (Bradshaw and Eglinton, 1993 and references therein). Among those compounds, lipids (such as fatty acids) appear particularly important due to their key role in the transfer of carbon and energy through aquatic food webs (Müller-Navarra et al., 2000). Moreover, the specific structure of some lipids allow them to be widely used as biomarkers in geochemical studies for determining the source, the transformation and the fate of OM (Grossi et al., 2003 and references therein).

The differential digestion of bacteria and the release of enteric bacteria by marine deposit-feeders have been demonstrated. This can lead to structural shifts of the bacterial assemblages in faeces compared to the ingested sediment, and affect bacterial population dynamics by cellular destruction (bacteriolytic activity) and/or by stimulating growth during passage through the digestive tract (Dobbs and Guckert, 1988; Wilde and Plante, 2002; Lucas et al., 2003).

It is thus evident that the overall feeding activity of worms (ingestion of sediment/egestion of faecal material) influences the quality and the quantity of the OM, but also its subsequent evolution. However, to the best of our knowledge, there have been few studies at the molecular level on both the direct (i.e. gut transit) and the indirect (i.e. bacterial inoculation and ageing) impact

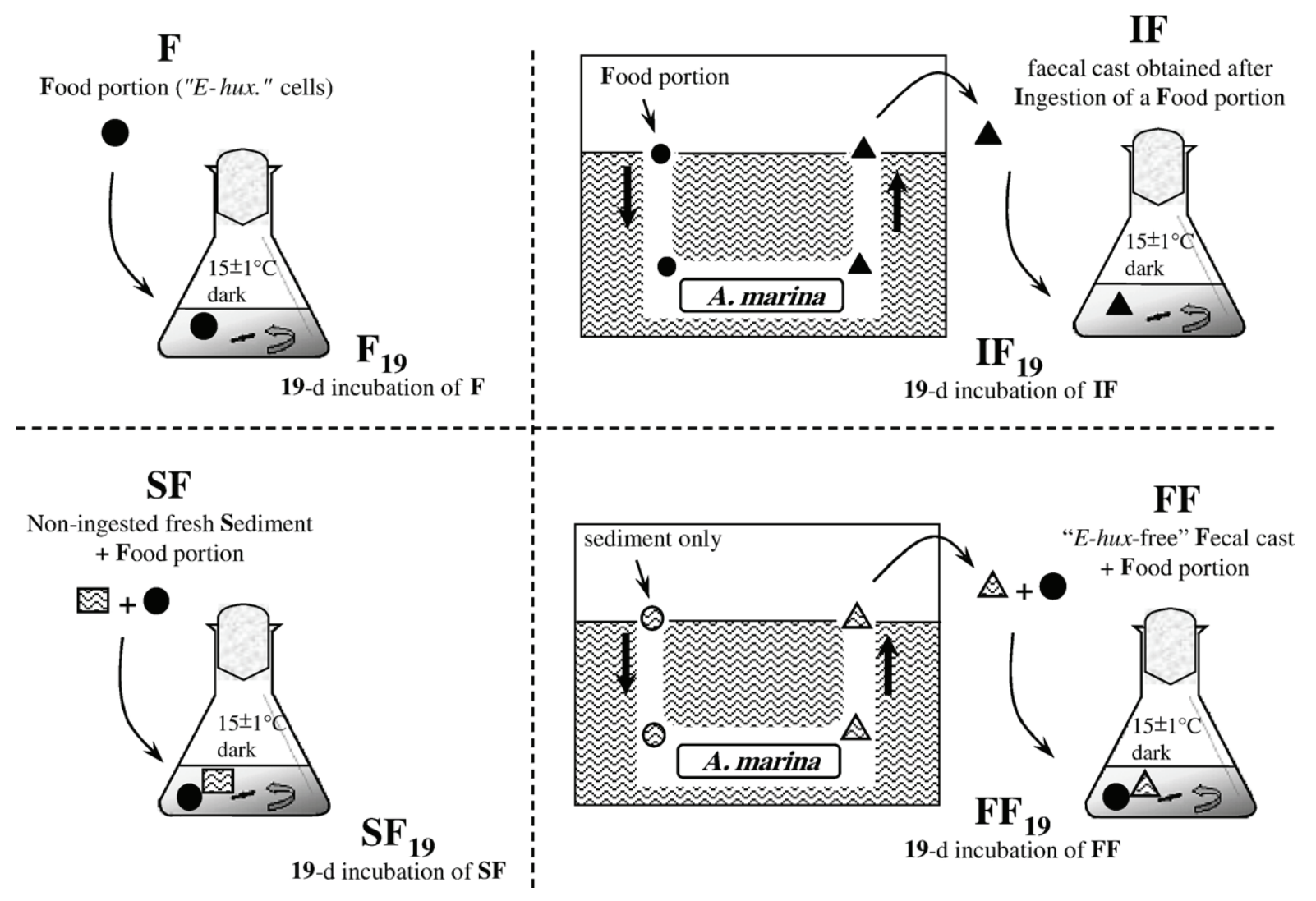

Fig. 1. Outline of the experimental design. 
Table 1

Samples description and analyses performed

\begin{tabular}{|c|c|c|c|c|}
\hline Samples & Description $^{\mathrm{a}}$ & Qualitative changes in FA & Quantitative changes in FA & DNA analyses \\
\hline $\mathbf{F}$ & Food portion & $\mathrm{X}$ & n.d. ${ }^{b}$ & n.d. \\
\hline $\mathbf{F}_{19}$ & 19d-incubation of $\mathbf{F}$ & $\mathrm{X}$ & n.d. & n.d. \\
\hline IF & Faecal cast obtained after Ingestion of a Food portion & $\mathrm{X}$ & n.d. & n.d. \\
\hline $\mathbf{I F}_{19}$ & 19d-incubation of IF & $\mathrm{X}$ & n.d. & n.d. \\
\hline FF & "E. hux-free" Faecal cast + Food portion & $\mathrm{X}$ & $\mathrm{X}$ & $\mathrm{X}$ \\
\hline $\mathrm{FF}_{19}$ & 19d-incubation of FF & $\mathrm{X}$ & $\mathrm{X}$ & $\mathrm{X}$ \\
\hline SF & Non-ingested fresh Sediment + Food portion & $\mathrm{X}$ & $\mathrm{X}$ & $\mathrm{X}$ \\
\hline $\mathbf{S F}_{19}$ & 19d-incubation of SF & $X$ & $X$ & X \\
\hline
\end{tabular}

a See Experimental design section for the rationale behind each individual treatment.

b n.d. = not determined.

of deposit-feeders on the fate of dietary lipids. To address these questions, dead phytoplanktonic cells (food portions) were fed to the lugworm Arenicola marina (L.) and subsequently incubated, or directly incubated in the presence of fresh egesta or non-ingested sediment. Changes in fatty acid composition and structure of bacterial communities during gut transit and/or incubation were then monitored using gas-chromatography/massspectrometry and a DNA fingerprint approach, respectively. This allowed to specifically determine i) the fate of dietary fatty acids during gut transit of $A$. marina and, ii) the potential influence of $A$. marina's faeces (i.e. bacterial inoculation and ageing) on the evolution of fatty acid distribution and bacterial community structure in superficial sediments.

\section{Material and methods}

\subsection{Material}

Seawater and sediment were collected manually from Carteau beach (Gulf of Fos, Mediterranean Sea). This sediment is occupied by a macrofauna assemblage characteristic of sandy areas with a dominant contribution of polychaetes, from which sampled Arenicolidae individuals (A. claparedii) were too small to be used in our experiment. The sediment was maintained in isothermic bags during its transportation to the laboratory where it was sieved $(1 \mathrm{~mm})$ to remove all large organisms, homogenised and stored at $15 \pm 1{ }^{\circ} \mathrm{C}$ before use. The same sediment was used all along the study.

A. marina (L.) was provided by the company "Normandie Appats". A. marina was chosen as a model deposit-feeder as it is a dominant macrobenthic species along Western European coasts (Retraubun et al., 1996; Riisgård and Banta, 1998). A. marina assimilates OM from different food sources (Grossmann and Reichardt, 1991; Retraubun et al., 1996; Andresen and Kristensen,
2002), and ejects characteristic faecal casts at the surface of the sediment (Riisgård and Banta, 1998). Animals used in the experiment $(\sim 4 \mathrm{~g}$ wet weight $)$ were collected in the Bay de Somme (Channel, France) at a temperature close to our experimental temperature, one day prior to their introduction in tanks containing sieved sediment. There, animals were allowed to acclimatise for two weeks at $15 \pm 1{ }^{\circ} \mathrm{C}$ before the beginning of the experiment.

For the experiment, the marine phytoplankton Emiliania huxleyi strain CS-57 (CSIRO Collection of Living Microalgae) was used to prepare food portions. $E$. huxleyi is an ubiquitous phototrophic eukaryote which constitutes a high proportion of marine biomass and which can contribute to significant inputs of $\mathrm{OM}$ to sediments (Conte et al., 1995). Batch cultures were grown non-axenically to the stationary phase at $15{ }^{\circ} \mathrm{C}$ with Si-free $\mathrm{f} / 2$ medium. Cells were harvested by centrifugation, freeze-dried, and mixed with sieved sediment ( $1 \mathrm{~g}$ freeze-dried cells/100 $\mathrm{g}$ wet sediment) for an accurate splitting into food portions $(2.9 \pm 0.1 \mathrm{~g})$, and to facilitate feeding of individual $A$. marina. Those food portions were kept frozen until the beginning of the experiment.

\subsection{Experimental design}

The experimental design is outlined in Fig. 1. At the beginning of the experiment, selected individual $\mathrm{A}$. $\mathrm{ma}$ rina were introduced either in U-shaped PVC tubes or in aquaria, each filled with fresh (sieved) sediment. Each worm living in a U-shaped tube was fed with one food portion and the corresponding faecal cast was collected, whereas worms living in aquaria fed on the surrounding sediment and produced the so-called " $E$. hux-free" faecal casts. Then, different incubation experiments (i.e. ageing) were performed under aerobic conditions (19 days, $15 \pm$ $1{ }^{\circ} \mathrm{C}$, dark) with $10 \mathrm{ml}$ of filtered and sterilized seawater. 
The different samples considered and the rationale behind

- Individual food portions (samples $\mathrm{F} ; n=6$ ) used as a source of dietary fatty acids;

- Faecal casts produced by $A$. marina fed with a food portion (samples IF; $n=4$ ) which allowed to determine the impact of gut transit on F;

- "E. hux-free" faecal casts individually mixed with one food portion (1:4, weight/weight) (samples FF; $n=6$ ) designed to study the ageing of $\mathrm{F}$ after indirect bacterial inoculation by $A$. marina (i.e. indirect impact of feeding);
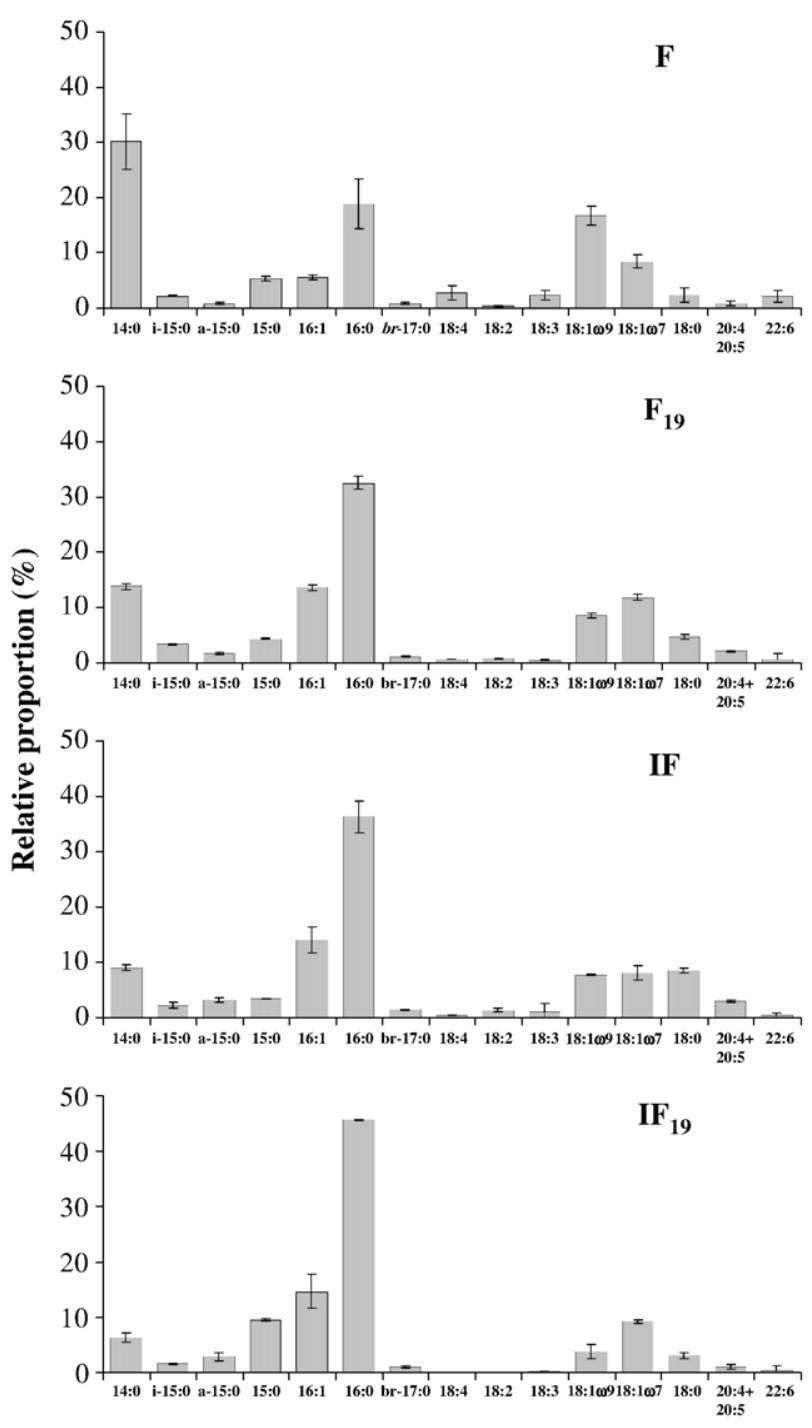
each experimental treatment is:

- Non-ingested (sieved) sediment mixed with one food portion (1:4, weight/weight) (samples SF; $n=6$ ) designed as a control for the latter treatment.

Half of each sample set was stored for lipid and/or DNA analysis, whereas the other half was incubated for 19 days (to mimic ageing of detritus) as described above, yielding samples $\mathrm{F}_{19}, \mathrm{IF}_{19}, \mathrm{FF}_{19}$ and $\mathrm{SF}_{19}$ (Fig. 1 and Table 1).

\subsection{Extraction and analysis of lipids}

Each sample was extracted 5 times ultrasonically with a mixture of methylene chloride-methanol-water
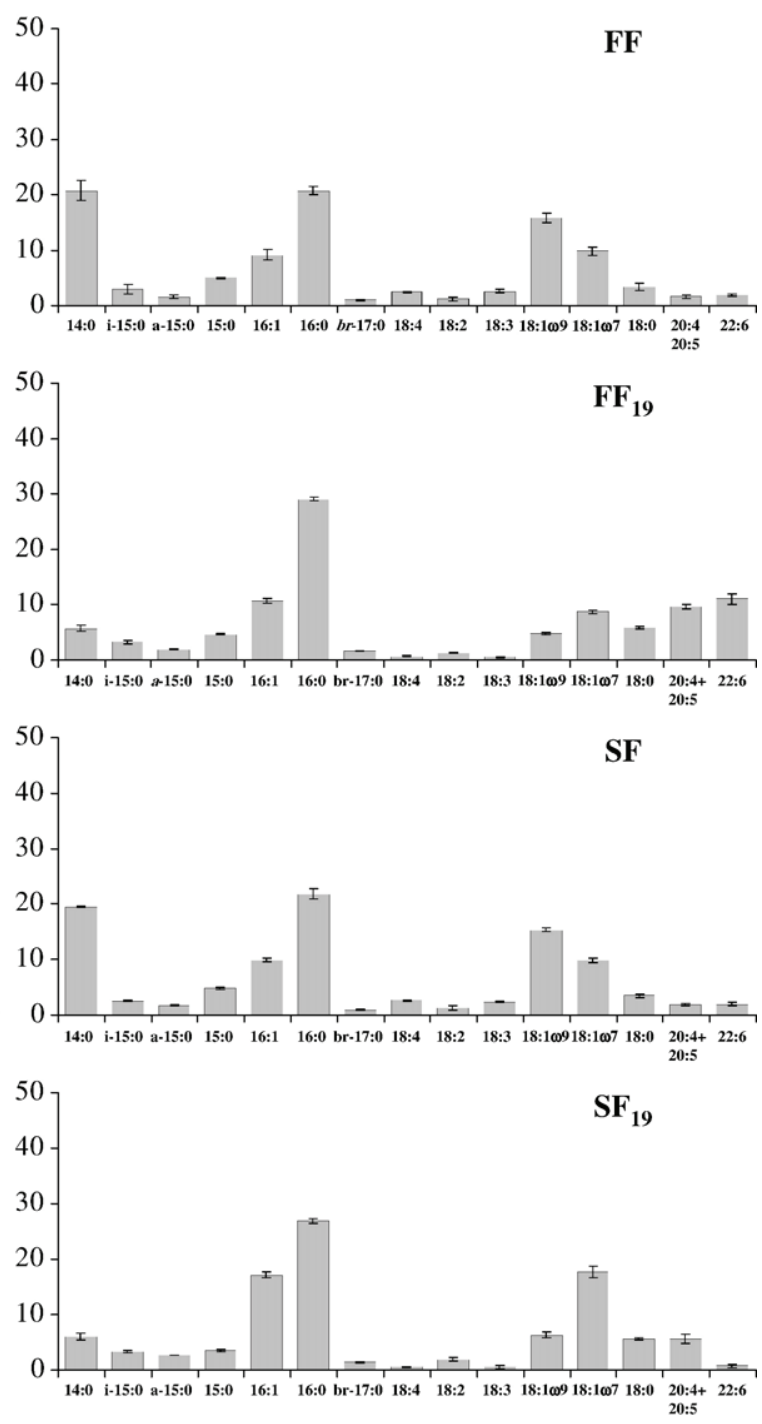

Fatty acids

Fig. 2. Relative proportions of individual fatty acids in all non-incubated and incubated samples (mean \pm S.D.; $n=2$ for IF and $\mathrm{IF}_{19}$ and $n=3$ for all other samples). $i$-, $a$ - and $b r$ - refer to iso-, anteiso- and undefined branched fatty acids, respectively. See Table 1 for samples description. 


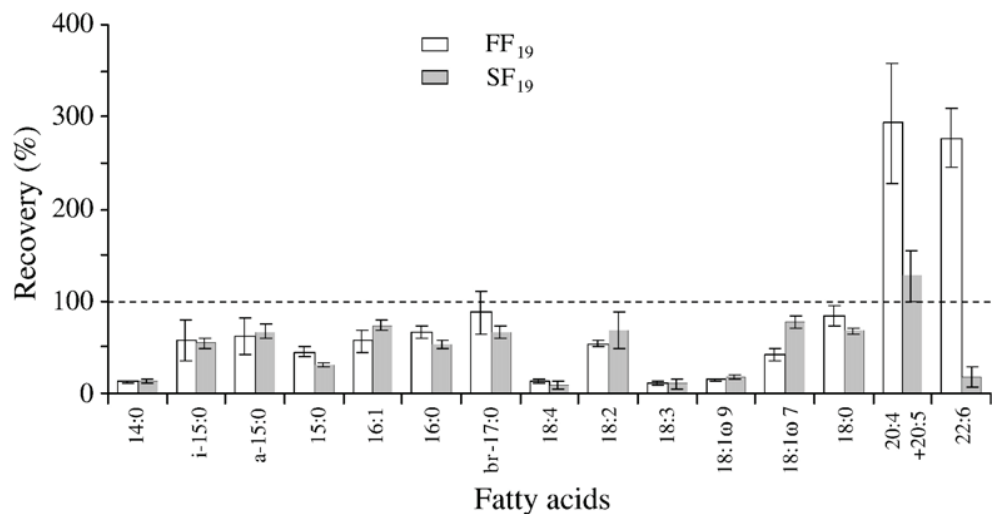

Fig. 3. Recovery percentages of fatty acids after 19 d-incubation of FF and SF samples (mean \pm S.D.; $n=3$ for each condition). See Table 1 for samples description.

(DCM-MeOH- $\mathrm{H}_{2} \mathrm{O}, 20 \mathrm{ml}$, volume ratio $1: 2: 0.8$ ). DCM and $\mathrm{H}_{2} \mathrm{O}$ were added to the combined extracts to bring the $\mathrm{DCM}-\mathrm{MeOH}-\mathrm{H}_{2} \mathrm{O}$ volume ratio to $1: 1: 0.9$, which allowed two solvent layers to separate. Lipids were recovered in the lower DCM phase and the aqueous phase was extracted again twice with DCM. The combined organic extracts were concentrated by rotary evaporation and saponified with $1 \mathrm{~N} \mathrm{KOH}$ in $\mathrm{MeOH} /$ $\mathrm{H}_{2} \mathrm{O}$ (volume ratio $1: 1$, reflux $2 \mathrm{~h}$ ). After extraction of the neutral lipids from the basic solution ( $n$-hexane, $3 \times 20 \mathrm{ml}$ ), acids were extracted (DCM, $3 \times 20 \mathrm{ml})$ following addition of $\mathrm{HCl}(\mathrm{pH}=2)$.

Fatty acids were converted to trimethylsilyl-derivatives by reaction with bis-trimethylsilyl-trifluoroacetanamide (Supelco) in pyridine (volume ratio 1:1; $30 \mathrm{~min}$ at $60{ }^{\circ} \mathrm{C}$ ). Arachidic acid (Sigma) was used as an internal standard for fatty acid quantification. Individual compounds were identified and quantified using a HP 5890 Series II Plus gas chromatograph coupled to a HP 5972 mass spectrometer, operated at $70 \mathrm{eV}$ with a mass range $m / z 50-700$. The gas chromatograph was equipped with an on-column injector and a Solgel-1 capillary column (30 $\mathrm{m} \times 0.25 \mathrm{~mm}$ i.d., $0.25 \mu \mathrm{m}$ film thickness), and Helium was used as the carrier gas. Samples were injected at $60{ }^{\circ} \mathrm{C}$ and the oven temperature was programmed from 60 to $130{ }^{\circ} \mathrm{C}$ at $20^{\circ} \mathrm{C} / \mathrm{min}$ and then at $4{ }^{\circ} \mathrm{C} / \mathrm{min}$ to $300{ }^{\circ} \mathrm{C}$ at which it was held for $10 \mathrm{~min}$.

\subsection{Extraction and analysis of DNA}

The protocol for DNA extraction was modified from Tsai and Olson (1991). Freeze-dried portions of the FF, $\mathrm{FF}_{19}$, SF and $\mathrm{SF}_{19}$ samples were carefully ground, and triplicate subsamples ( $0.25 \mathrm{~g}$ dry weight) of each portion were mixed with $500 \mu \mathrm{l}$ of TES buffer $(100 \mathrm{mM}$ Tris$\mathrm{HCl}[\mathrm{pH}=8.0], 100 \mathrm{mM} \mathrm{Na}{ }_{2} \mathrm{HPO} 4[\mathrm{pH}=8.0], 100 \mathrm{mM}$
$\mathrm{Na}_{2}$ EDTA $[\mathrm{pH}=8.0], 1.5 \mathrm{M} \mathrm{NaCl}$ ). Three cycles of freezing (liquid nitrogen, $2 \mathrm{~min}$ ) and thawing (water bath $100{ }^{\circ} \mathrm{C}, 2 \mathrm{~min}$ ) were conducted to allow the lysis of microbial cells (Roose-Amsaleg et al., 2001). Lysozyme (10 mg, Sigma) and proteinase K ( $7 \mu \mathrm{l}$ of a $10 \mathrm{mg} \mathrm{ml}^{-1}$ solution, Boehringer Mannheim) were then added to the samples which were incubated for $2 \mathrm{~h}$ at $37{ }^{\circ} \mathrm{C}$ under agitation $(300 \mathrm{rpm})$. Following the addition of hexadecyltrimethylammonium bromide (10 $\mathrm{mg}$, Sigma), the samples were further incubated for $2 \mathrm{~h}$ at $65^{\circ} \mathrm{C}$ under agitation (300 rpm) before centrifugation at 12,000 $\times g$ $\left(20{ }^{\circ} \mathrm{C}, 15 \mathrm{~min}\right)$. Supernatants were mixed with an equal volume of chloroform-isoamyl alcohol (volume ratio 24:1). The aqueous phase was recovered by centrifugation $\left(12,000 \times g, 20^{\circ} \mathrm{C}, 15 \mathrm{~min}\right)$ and precipitated with isopropanol overnight at room temperature. The crude DNA pellets were obtained by centrifugation at 15,000 $\times g$ (room temperature, $30 \mathrm{~min}$ ) and were gently washed with $70 \%$ ethanol $\left(-20^{\circ} \mathrm{C}\right)$. Ethanol was removed after centrifugation $\left(15,000 \times \mathrm{g}, 20^{\circ} \mathrm{C}, 15 \mathrm{~min}\right)$ and air-drying (10-15 min). The pellets were suspended in $50 \mu \mathrm{l}$ of sterile ultra pure water and stored at $-20{ }^{\circ} \mathrm{C}$.

rRNA intergenic spacer analysis (RISA) was used to characterize changes in the genetic structure of bacterial communities (Acinas et al., 1999; Ranjard et al., 2000). Amplification reactions were performed in a final volume of $50 \mu \mathrm{l}$ containing HighFidelity buffer $(5 \mu \mathrm{l}$ of $10 \times$ dilution), $\mathrm{MgCl}_{2}(2.5 \mathrm{mM})$, dNTP (200 $\mu \mathrm{M}$ of each), primers (25 pmol of each), T4 gene 32 protein (1 $\mu \mathrm{g}$, Boehringer Mannheim), and TripleMaster polymerase (1.75 units, Eppendorf AG). Reactions were performed in an automated DNA thermal cycler (Eppendorf Mastercycler) for 25 cycles. After an initial denaturation step $(30 \mathrm{~s}$. at $94^{\circ} \mathrm{C}$ ), each cycle consisted of a denaturing step ( $1 \mathrm{~min}$ at $94^{\circ} \mathrm{C}$ ), annealing at $55^{\circ} \mathrm{C}$ for $30 \mathrm{~s}$ and an extension step of $1 \mathrm{~min}$ at $72^{\circ} \mathrm{C}$. A final elongation step at $72^{\circ} \mathrm{C}$ for $5 \mathrm{~min}$ 

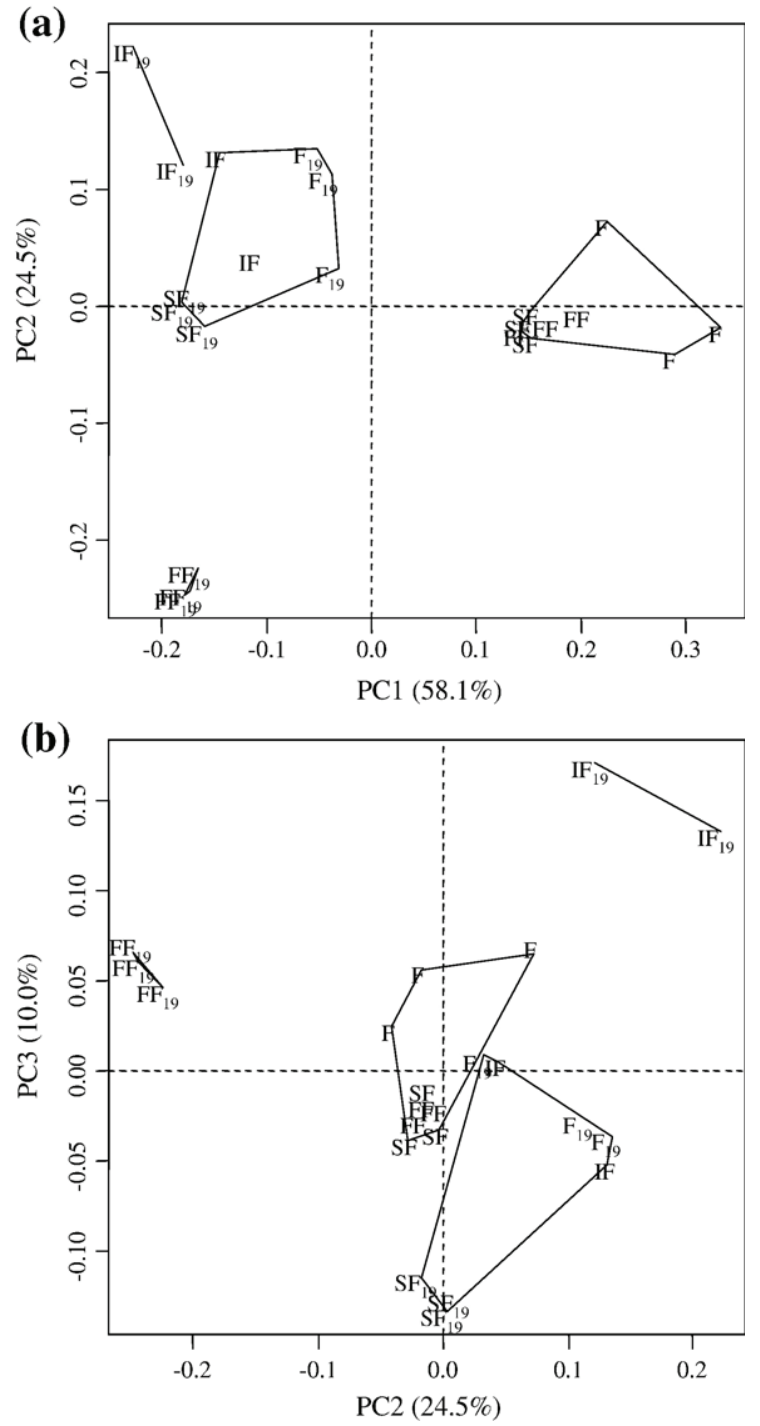

Fig. 4. Plots of the first (PC1) and second (PC2) (a) and of the second (PC2) and third (PC3) (b) principal components derived from PCA of the relative distribution of individual fatty acids in all non-incubated and incubated samples (see Table 1 for samples description). Linelinked observations correspond to boundaries of K-means clusters. Replicates always belong to the same clusters.

preceded cooling at $4{ }^{\circ} \mathrm{C}$. PCR products $(16 \mu \mathrm{l})$ were loaded on a 5\% non-denaturing acrylamide gel $(N$ acrylamide $/ N$-methylenebisacrylamide, 29:1, Bio-Rad) and separated by electrophoresis (DSG200-02, C.B.S. Scientific) for $15 \mathrm{~h}$ at $8 \mathrm{~mA}$. Gels were stained with SYBR green I (FMC Bioproducts) according to the manufacturer's instructions. RISA profiles were photographed and analysed using a Quantity One GelDoc2000 system (Bio$\mathrm{Rad}$ ) yielding data matrices which were used for principal component analysis (PCA). Those matrices took into account the presence or absence of bands and their normalized intensity. RISA profiles were assumed to be indicative of the main bacterial community changes, and variation between RISA profiles generated from different samples was assumed to reflect variation in the corresponding bacterial communities (Yannarell and Triplett, 2004).

\subsection{Principal component analysis and classification}

Two Principal component analyses (PCA) were carried out to analyse variations in fatty acid distribution (relative abundances) and bacterial community RISA profiles amongst non-incubated and incubated samples. In both cases, we disposed of a sequence of $n$ observations (fatty acid distributions or RISA profiles) $\left\{x_{i}\right.$, $i=1, \ldots, n\}$, caracterized by $p$ variables (each peak) such that $x_{i}=\left(f_{i 1}, \ldots, f_{i p}\right)$ with:

$$
\left\{\begin{array}{c}
f_{i k} \geq 0, k=1, \ldots, p, i=1, \ldots, n \\
\sum_{k=1}^{p} f_{i k}=1, i=1, \ldots, n
\end{array}\right.
$$

that were row-combined into a single matrix $X$.

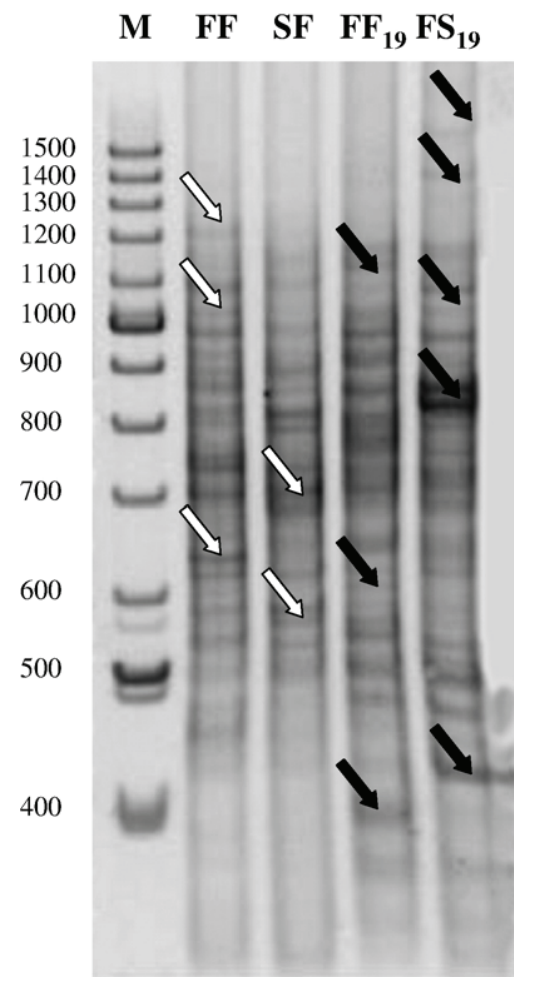

Fig. 5. RISA profiles from the incubated and non-incubated $\mathrm{FF}$ and SF samples. Black and white arrows respectively indicate major discriminating bands between incubated and non-incubated FF and SF samples. M: molecular markers (bp). 
Once the PCA of $X$ performed (i.e. the eigenvalue decomposition of the covariance matrix of $X$ in order to determine the main directions into the observations space along which the data have the highest variability; Hastie et al., 2001), the initial table $X$ was resumed through a matrix $Y$ of $m<p$ principal components accounting for a given quantity of variability (e.g. 90\%). The other components accounting for small proportions of the total variance were discarded. The K-means clustering method was then applied to $Y$ to gather observations lying in the space of the $m$ first principal components (Hastie et al., 2001). This twosteps procedure (PCA $+\mathrm{K}$-means classification) allowed gathering observations that were most similar regarding the squared Euclidean distance between observations. A filtering step via the PCA was simply considered to make the K-means clusters more robust. Results of the classification were displayed in the form of convex envelops into the 2-dimensional plots of the PCA.

\section{Results}

Table 1 presents the different types of samples considered in this study and the analyses performed. Due to our experimental design, A. marina living in the Ushaped tubes likely ingested some of the surrounding sediment in addition to the food portions (Fig. 1). The quantitative impact of $A$. marina's gut transit on fatty acid distribution (comparison between $\mathrm{F}$ and IF samples) was therefore not possible, and only qualitative changes were considered for those samples. However, the influence of egested bacterial communities on the fatty acid distribution of aged faecal casts ( $\mathrm{FF}$ and $\mathrm{FF}_{19}$ samples), could be qualitatively and quantitatively compared with that of non-ingested sediment ( $\mathrm{SF}$ and $\mathrm{SF}_{19}$ samples), owing to the use of similar dilution rates of food portions. For those latter samples (FF, $\left.\mathrm{FF}_{19}, \mathrm{SF}, \mathrm{SF}_{19}\right)$, the varying fatty acid distribution was simultaneously compared with changes in the genetic structure of the bacterial communities assessed by DNA fingerprinting (Table 1).

\subsection{Changes in fatty acids distribution}

Fifteen major fatty acids present in the food mixture (F) were considered for this study (Fig. 2). Although some fatty acids were present in the original sediment which was used to prepare the food portions, the mixing with non-axenic $E$. huxleyi cells induced an enrichment $\geq 95 \%$ for each component. The $\mathrm{C}_{14: 0}, \mathrm{C}_{16: 0}, \mathrm{C}_{18: 1 \omega 9}$, and $\mathrm{C}_{18: 1 \omega 7}$ were the most abundant compounds and contributed to ca. $75 \%$ of the total fatty acids. The presence of branched odd-carbon-number fatty acids in food portions suggests the presence of bacteria in the cultured E. huxleyi.
Ingestion of a food portion by $A$. marina resulted in a significant increase of the relative proportions of $\mathrm{C}_{16: 0}$, $\mathrm{C}_{16: 1}, \mathrm{C}_{18: 0}$ and $\mathrm{C}_{18: 1 \omega 7}$ fatty acids, and in the concomitant decrease of $\mathrm{C}_{14: 0}$ and $\mathrm{C}_{18: 1 \omega 9}$ homologues (Fig. 2, F and IF). Gut transit also induced a pronounced decrease in relative abundances of $\mathrm{C}_{18: 3}, \mathrm{C}_{18: 4}$ and $\mathrm{C}_{22: 6}$ components, whereas $\mathrm{C}_{20: 4+20: 5}$ fatty acids slightly increased from 2 to ca. $6 \%$. Incubation of a food portion for 19 days induced similar changes in the overall distribution of fatty acids as gut transit (Fig. 2, $\mathrm{F}_{19}$ and IF) but also a further decrease in $\mathrm{C}_{18: 1 \omega 9}$ fatty acid and the complete removal of $\mathrm{C}_{18}$ polyunsaturated fatty acids (PUFAs).

The mixing of food portions with either " $E$. hux-free" faecal casts (FF samples) or fresh sediment (SF samples), induced only small changes in the relative fatty acid distribution (Fig. 2). The most significant change was observed for the $\mathrm{C}_{14: 0}$ fatty acid, the relative proportion of which decreased by $10 \%$ compared to the original food portion. As observed for food portions alone, the proportion of $\mathrm{C}_{14: 0}$ and $\mathrm{C}_{18: 1 \omega 9}$ fatty acids and of most $\mathrm{C}_{18}$ PUFAs decreased during incubation of $\mathrm{FF}$ and $\mathrm{SF}$ mixtures, whereas those of $\mathrm{C}_{20}$ PUFAs significantly increased, especially during the incubation of food portions in the presence of " $E$. hux-free" faecal casts (Fig. 2, $\mathrm{FF}_{19}$ ). This latter condition of incubation also induced a 4 times increase of the proportion of the $\mathrm{C}_{22}$ PUFA, which exhibited a decrease during all incubations (Fig. 2, $\mathrm{F}_{19}, \mathrm{IF}_{19}$ and $\mathrm{SF}_{19}$ ).

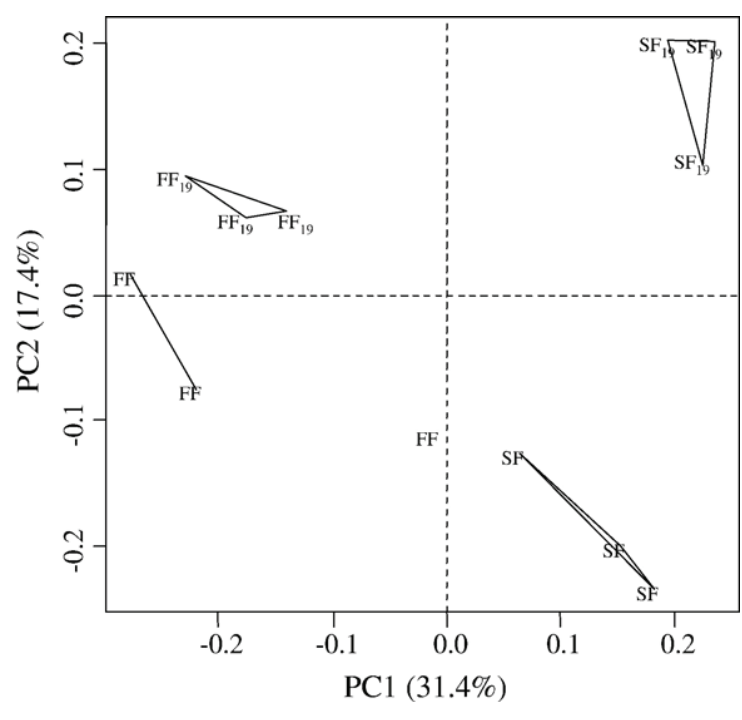

Fig. 6. Comparison of the bacterial communities structure in nonincubated and incubated FF and SF samples (see Table 1 for samples description). Plot of first (PC1) and second (PC2) principal components derived from PCA of RISA profiles. Observations belonging to the same cluster are linked with a black line. 
Table 2

Relative proportions of different classes of fatty acids in the different samples (see Table 1 for samples description)

\begin{tabular}{|c|c|c|c|c|c|}
\hline \multirow[t]{2}{*}{ Samples } & $\sum$ saturated & $\sum$ branched & $\sum$ monounsaturated & $\sum$ PUFAs & $\sum$ unsaturated \\
\hline & $\mathrm{FA}(\%)^{* * *}$ & FA $(\%)$ & FA $(\%)$ & $(\%)$ & FA $(\%)^{* * * *}$ \\
\hline $\mathrm{F}^{*}$ & 60 & 4 & 31 & 9 & 40 \\
\hline $\mathrm{F}_{19}^{*}$ & 61 & 6 & 34 & 5 & 39 \\
\hline $\mathrm{IF}^{* *}$ & 64 & 7 & 30 & 6 & 36 \\
\hline $\mathrm{IF}_{19} * *$ & 70 & 6 & 28 & 2 & 30 \\
\hline $\mathrm{FF}^{*}$ & 55 & 5 & 35 & 10 & 45 \\
\hline $\mathrm{FF}_{19} *$ & 52 & 7 & 24 & 24 & 48 \\
\hline $\mathrm{SF}^{*}$ & 55 & 5 & 35 & 10 & 45 \\
\hline $\mathrm{SF}_{19}$ & 49 & 7 & 41 & 10 & 51 \\
\hline
\end{tabular}

*average of triplicate samples, **average of duplicate samples, ***including bacterial branched FA, ****sum of monounsaturated + PUFAs.

Pronounced quantitative changes of the fatty acid distribution were also observed in 19d-incubated SF and FF samples (Fig. 3). All but $\mathrm{C}_{20}$ and $\mathrm{C}_{22}$ fatty acids showed a sharp decrease in concentration upon incubation. The greater losses $(>80 \%)$ were observed for the $\mathrm{C}_{14: 0}$ and the (poly)unsaturated $\mathrm{C}_{18: 4}, \mathrm{C}_{18: 3}$ and $\mathrm{C}_{18: 1 \omega 9}$ fatty acids, whereas the amounts of $\mathrm{C}_{15: 0}, \mathrm{C}_{16: 0}, \mathrm{C}_{17: 0}$, $\mathrm{C}_{18: 1 \omega 7}$ and $\mathrm{C}_{18: 2}$ fatty acids decreased to a lower extent (15-40\%). Similar to the qualitative observations, the concentrations of $\mathrm{C}_{20}$ and $\mathrm{C}_{22}$ PUFAs increased by 3-fold during incubation of food portions in the presence of " $E$. hux-free" faecal casts (Fig. 3, FF 19 ). A lower but significant increase in $\mathrm{C}_{20}$ PUFAs concentration ( $\mathrm{Rec}=$ $\sim 130 \%$ ) was also observed during incubation in the presence of non-ingested fresh sediment, while only $18 \%$ of the initial $\mathrm{C}_{22: 6} \mathrm{FA}$ remained after incubation under these conditions (Fig. 3, $\mathrm{SF}_{19}$ ).

The qualitative fatty acid distribution in all incubated and non-incubated samples was further analysed through PCA (Fig. 4). Components 1, 2, and 3 accounted for a total of $92 \%(58,25$ and $10 \%$, respectively) of the variability amongst all samples. The first component distinguished ingested and/or incubated samples $\left(\mathrm{F}_{19}, \mathrm{IF}, \mathrm{IF}_{19}\right.$, $\mathrm{FF}_{19}, \mathrm{SF}_{19}$ ) from those that were neither ingested nor incubated (F, FF, SF; Fig. 4a). To better explain the variations in fatty acid distribution observed during the different experimental treatments, PCA was considered for the second and the third components (Fig. 4b). This clearly distinguished all incubation conditions from one another and confirmed that ingestion (IF) or 19d-incubation $\left(F_{19}\right)$ of food portions resulted in similar qualitative changes in fatty acids distribution.

\subsection{Changes in bacterial communities}

RISA profiles obtained before incubation of FF and SF samples already showed some differences in the dominant bacterial communities present in the two types of samples
(Fig. 5); this was likely due to the presence of enteric bacteria in the egested sediment and/or to the preferential removal of certain types of bacteria during gut transit. Incubation of those samples during 19 days induced a clear and distinct evolution of the bacterial community structure for both conditions. These changes were determined from the RISA profiles which showed a decrease or an increase of the relative intensity of pre-existing bands, and by the appearance or disappearance of other bands (Fig. 5).

Differences of bacterial community structure in incubated and non-incubated FF and SF samples were further confirmed by PCA analysis of the RISA profiles. Components 1,2 , and 3 explained $61 \%$ of the data variance (31, 17 and $13 \%$, respectively). The first principal component clearly discriminated between SF and FF experimental conditions whereas changes during incubation were essentially explained by the second principal component (Fig. 6).

\section{Discussion}

\subsection{Direct influence of feeding}

A common effect of marine food webs on dietary fatty acids is the preferential assimilation and/or degradation of (poly)unsaturated fatty acids, resulting in a relative increase of the proportion of saturated homologues in the egested material. However, in the case of benthic invertebrates, the effect appears species dependent (e.g. Bradshaw et al., 1990b; Meziane et al., 2002). Deposit-feeder activity can also result in minor changes of the fatty acid distribution or in an enrichment of the monounsaturated fatty acid content of sediments (Bradshaw and Eglinton, 1993 and references therein). In the present case, faecal casts produced from food portions were slightly enriched in saturated fatty acids relative to (poly)unsaturated ones (Table 2, F and IF), 
although we could not determine the quantitative variations of the different classes of compounds during gut transit. This relative increase of saturated fatty acids was partly explained by an increase of branched $\mathrm{C}_{15: 0}$ and $\mathrm{C}_{\text {17:0 }}$ bacterial fatty acids (Fig. 2 and Table 2). The greater proportions of some individual fatty acids in the egested material could be due to the selective adsorption of other homologues by the worm and/or to a release from gut cells/microbes. It has already been suggested that an increase in branched $\mathrm{C}_{15}$ and $\mathrm{C}_{17}$ fatty acids in faeces of different marine invertebrates reflects a contribution from enteric bacteria (Harvey et al., 1987; Bradshaw et al., 1990b). Variations in the distribution of bacterial fatty acids (i.e. $\mathrm{C}_{18: 1 \omega 7}$ and branched $\mathrm{C}_{15: 0}$ and $\mathrm{C}_{17: 0}$ ) during feeding of $A$. marina may be further explained by differential digestibility of killed bacterial communities present in the original food portions. Plante and Shriver (1998) indeed demonstrated that only 11 of 43 bacterial species isolated from intertidal sediments were digested in gut extracts from A. marina. Feeding by $A$. marina did not change the relative proportion of the $\mathrm{C}_{18: 1 \omega 7}$ fatty acid but induced a significant decrease of the proportion of the $\mathrm{C}_{18: 1 \omega 9}$ isomer (Fig. 2, F and IF). Invertebrate herbivory is generally considered to have the inverse effect on $\mathrm{C}_{18}$ monounsaturated fatty acids, as faeces often contain a predominance of the $\omega 9$ isomer even when the diet contain the reverse (Bradshaw et al., 1990a, 1991; Bradshaw and Eglinton, 1993; Meziane et al., 2002); this is typically attributed to an animal contribution of the $\omega 9$ isomer which is usually the dominant isomer in animal tissues. Interestingly, the polychaete Nereis diversicolor was also shown to affect the distribution of $\mathrm{C}_{18: 1}$ fatty acids in a different way from other invertebrates (Bradshaw et al., 1990b). This suggests that polychaete worms have a distinct dietary impact on the sedimentary fatty acid distribution compared to other invertebrate species.

Although ingestion of food portions by A. marina induced significant variations in the relative (and probably quantitative) distribution of individual fatty acids, all major dietary fatty acids were still detected in the produced faecal casts (Fig. 2, F and IF). The further (sometimes complete) removal of (poly)unsaturated fatty acids during 19d-incubation of those faeces (Fig. 2 and Table 2, IF and $\mathrm{IF}_{19}$ ) could be attributed to microbial degradation. Moreover, the greater removal of (poly)unsaturated fatty acids during incubation of preingested food portions compared to non-ingested ones (Table 2, $\mathrm{IF}_{19}$ and $\mathrm{F}_{19}$ ) suggested that these compounds were more accessible to biodegradation after passage through the gut of A. marina.
The differences in the structure of bacterial communities between FF and SF samples reflected the direct impact of A. marina on sedimentary bacteria, when the lugworm was allowed to feed on sieved sediment. These results are in good agreement with previous studies which clearly demonstrated, using a variety of approaches, compositional shifts in bacterial assemblages with passage through deposit-feeders gut (Dobbs and Guckert, 1988; Findlay et al., 1990; Grossmann and Reichardt, 1991; Wilde and Plante, 2002), although the degree and nature of the disturbance seems to vary among invertebrate taxa (Plante and Wilde, 2004). In all cases, the modification of the bacterial community can be attributed to the digestion of a subset of ingested bacteria with the concomitant stimulation or inoculation of other groups.

\subsection{Indirect influence of feeding (i.e. inoculation and ageing of faeces)}

The incubation of food portions in the presence of " $E$. hux-free" egesta (FF samples) yielded a very different qualitative distribution of fatty acids compared to ingested and subsequently incubated food portions (Figs. 2 and $4 \mathrm{~b}, \mathrm{FF}_{19}$ and $\mathrm{IF}_{19}$ ). The major difference was the significant increase of the proportions of $\mathrm{C}_{20}$ and $\mathrm{C}_{22}$ PUFAs during incubation in the presence of " $E$. huxfree" faecal casts whereas these compounds almost disappeared following direct feeding (Fig. 2 and Table 2, $\mathrm{FF}, \mathrm{FF}_{19}$ and $\left.\mathrm{IF}_{19}\right)$. The quantitative analysis of fatty acids in non-incubated and incubated $\mathrm{FF}$ samples further demonstrated the important production of $\mathrm{C}_{20}$ and $\mathrm{C}_{22}$ PUFAs during incubation (Fig. 3).

The analysis of $A$. marina's gut tissues indicated the presence of minor amounts of $\mathrm{C}_{20}-\mathrm{C}_{22}$ PUFAs (data not shown), but an input of these compounds from gut cells possibly released in the " $E$. hux -free" faecal casts could not explain an increase in concentration during incubation. On the other hand, a production from autotrophic benthic microalgae that might be present in the original sediment appears very unlikely since incubations were performed under complete darkness. Although we cannot totally discard the presence of mixotrophic organisms, our results likely indicate a bacterial origin of the $\mathrm{C}_{20}$ and $\mathrm{C}_{22}$ PUFAs produced during incubation of $\mathrm{FF}$ samples. $\mathrm{C}_{20}$ and $\mathrm{C}_{22}$ PUFAs have long time been considered to be characteristic of eukaryotes (Harwood and Russell, 1984), but there is growing evidence that specific bacterial strains can also biosynthesised these compounds in relatively high amount (Yano et al., 1997; Nichols, 2003). In the present case, the formation of PUFAs was obviously due to the presence of PUFA-producing bacteria in the " $E$. $h u x$-free" faecal casts. Those bacteria were either enteric bacteria that were 
released with the egesta, or ingested bacteria (present in the sediment used to fill the aquaria) that have survived gut passage. Both explanations are supported by the presence of specific bacterial groups (bands) clearly visible in the RISA profiles of the FF samples (Fig. 5).

$\mathrm{C}_{20}$ PUFAs were also produced (although to a much lesser extent) when food portions were incubated in the presence of non-ingested sediment but this was accompanied by a significant decrease in $\mathrm{C}_{22}$ PUFA concentration (Fig. 3, $\mathrm{SF}_{19}$ ). Since the incubation conditions of FF and SF samples were similar, we speculate that the preponderance of $\mathrm{C}_{22}$ PUFA in $\mathrm{FF}_{19}$ samples was due to the growth of released enteric bacteria. If so, the production of $\mathrm{C}_{20}$ PUFAs in $\mathrm{FF}_{19}$ and $\mathrm{SF}_{19}$ samples involved bacteria different from the enteric $\mathrm{C}_{22}$ PUFA-producing population. The greater production of $\mathrm{C}_{20}$ PUFAs in $\mathrm{FF}_{19}$ compared to $\mathrm{SF}_{19}$ may further reflect the presence of (at least two) different $\mathrm{C}_{20}$ PUFA-producing bacterial populations (one in the original sediment and one in the gut) or a stimulation (or an enrichment) of sedimentary $\mathrm{C}_{20}$ PUFA-producing bacteria during $A$. marina feeding. The fact that no relative increase in $\left(\mathrm{C}_{22}\right)$ PUFA was observed following ingestion and incubation of food portions (Fig. 2, $\mathrm{IF}_{19}$ ) does not seem contradictory to the above hypotheses. It is indeed possible that PUFA-producing bacteria were released in IF samples but that their abundance was too low and/or that the conditions were not good enough to allow a significant growth within 19 days.

Although the structure of the bacterial community was clearly different in non-incubated FF and SF samples (Figs. 5 and 6), those contained similar fatty acid distributions (Fig. 2). These fatty acid profiles reflect the preponderance of $E$. huxleyi cells in the samples. Incubation for 19 days of each series of samples induced significant shifts in the structure of the bacterial community (Figs. 5 and 6), in addition to the aforementioned changes in fatty distribution. Classical bacterial fatty acids (i.e. $\mathrm{C}_{18: 1 \omega 7}$ and branched $\mathrm{C}_{15: 0}$ and $\mathrm{C}_{17: 0}$ ) had relatively high percentages of recovery compared to other fatty acids (i.e. $\mathrm{C}_{18: 4}, \mathrm{C}_{18: 3}$, $\mathrm{C}_{18: 1 \omega 9}$ ) originating from dietary phytoplanktonic cells (Fig. 3). This indicates a significant microbial contribution to fatty acid in $\mathrm{FF}_{19}$ and $\mathrm{SF}_{19}$ and further supports a bacterial origin of the produced PUFAs. The distinct evolution of the bacterial community structure during incubation of FF and SF samples is in agreement with different PUFA-producing bacterial populations (see discussion above).

The strong bacterial production of PUFAs during incubation of faecal casts indicates that these bacteria could potentially contribute a substantial proportion of the $\mathrm{C}_{20}$ to $\mathrm{C}_{22}$ PUFAs level in sediment. This is of particular importance since bacteria present in egesta are generally considered to be of poor nutritional value as they are more likely to be resistant to digestion (Plante and Wilde, 2001). Colonization of PUFA-synthesizing bacteria on surficial sediment may represent an important source of these vital nutrients to high trophic levels, which are unable to synthesize essential PUFA de novo (Müller-Navarra et al., 2000). As far as we know, the presence of PUFA-producing bacteria in guts of marine lugworms has never been reported.

It should be noted, however, that the environmental relevance of our experimental observation may be limited since disturbances associated with gut passage are a function of numerous variables, including the longevity of faecal materials as distinct habitats. Our experimental design (i.e. incubation in separated flasks and long incubation time) favoured the regrowth of enteric bacteria and/ or bacteria that have survived gut passage, and precluded any recolonization of the faecal casts from bacteria in surrounding sediment. By using field manipulative experiments, Plante and co-authors (Plante and Wilde, 2001; Plante and Stinson, 2003) demonstrated that recolonization of naturally incubated faeces from different deposit feeders including the polychates $A$. cristata and N. succinea, occurred rapidly and was dominated by immigration from adjacent sediments. These authors recently confirmed the primary role of immigration using molecular techniques (Denaturing Gradient Gel Electrophoresis, DGGE) but, interestingly, also observed notable differences between the genetic fingerprints of naturally incubated egesta and surrounding sediments (Plante and Wilde, 2004). The presence of some unique DGGE bands in aged egesta might represent (bacterial) phylotypes introduced by the animals, which would agree with the different RISA profiles observed in the present study.

\section{Conclusions}

The present experimental work indicates that passage through the gut of $A$. marina can increase the proportions of (bacterial) saturated fatty acids relative to dietary (poly)unsaturated ones of ingested sediments, make some dietary fatty acids more accessible to subsequent biodegradation and, induce significant compositional shifts in sedimentary bacterial assemblages.

The results further show that $A$. marina's faeces can contain PUFA-producing bacterial populations which can be of relatively high nutritional value to other trophic levels which are unable to synthesize essential PUFAs de novo. Further work on the presence of PUFAproducing bacteria (isolation, phylogenetical affiliation, etc.) in guts of marine lugworms is undoubtedly needed. 


\section{Acknowledgements}

This work was supported by grants from CNRSINSU (ATI 2001). We thank the European Association of Organic Geochemists for financial support to S.C. (EAOG travel scholarships), Dr G. Stora for helpful discussion and Ms D. Raphel for help with microalgal culture. We are grateful to M. and D. Lopuszanski and G. Espeut from the "Normandie Appat" Company for the gift of A. marina specimens. An anonymous referee and the associate editor Dr. S. Shumway provided helpful comments on an earlier draft of this paper. This is Nereis Park contribution number 12. [SS]

\section{References}

Acinas, S.G., Anton, J., Rodriguez-Valera, F., 1999. Diversity of freeliving and attached bacteria in offshore western Mediterranean waters as depicted by analysis of genes encoding 16S rRNA. Appl. Environ. Microbiol. 65, 514-522.

Aller, R.C., Aller, J.Y., Kemp, P.F., 2001. Organism-Sediment Interactions. Bell W. Baruch Library in Marine Science, vol. 21. University of South Carolina Press.

Andresen, M., Kristensen, E., 2002. The importance of bacteria and microalgae in the diet of the deposit-feeding polychaete Arenicola marina. Ophelia 56, 179-196.

Banta, G.T., Holmer, M., Jensen, M.H., Kristensen, E., 1999. Effects of two polychaete worms, Nereis diversicolor and Arenicola marina, on aerobic and anaerobic decomposition in a sandy marine sediment. Aquat. Microb. Ecol. 19, 189-204.

Bradshaw, S.G., Eglinton, G., 1993. Marine invertebrate feeding and the sedimentary lipid record. In: Engel, M.H., Macko, S.A. (Eds.), Organic Geochemistry. Plenum Press, New York, pp. 225-235.

Bradshaw, S.A., O’Hara, S.C.M., Corner, E.D.S., Eglinton, G., 1990a. Changes in lipids during simulated herbivorous feeding by the marine crustacean Neomysis integer. J. Mar. Biol. Assoc. U.K. 70, 225-243.

Bradshaw, S.A., O’Hara, S.C.M., Corner, E.D.S., Eglinton, G., 1990b. Dietary lipid changes during herbivory and coprophagy by the marine invertebrate Nereis diversicolor. J. Mar. Biol. Assoc. U.K. $70,771-787$

Bradshaw, S.A., O’Hara, S.C.M., Corner, E.D.S., Eglinton, G., 1991. Effects on dietary lipids of the marine bivalve Scrobicularia plana feeding in different modes. J. Mar. Biol. Assoc. U.K. 71, 635-653.

Conte, M.H., Thompson, A., Eglinton, G., 1995. Lipid biomarker diversity in the coccolithophorid Emiliania huxleyi (Prymnesiophyceae) and the related species Gephyrocapsa oceanica. J. Phycol. 31, 272-282.

Dobbs, F.C., Guckert, J.B., 1988. Microbial food resources of the macrofaunal-deposit feeder Ptychodera bahamensis (Hemicordata: Enteropneusta). Mar. Ecol. Prog. Ser. 45, 127-136.

Findlay, R.H., Trexler, M.B., White, D.C., 1990. Response of a benthic microbial community to biotic disturbance. Mar. Ecol. Prog. Ser. $62,135-148$

Grossi, V., Caradec, S., Gilbert, F., 2003. Burial and reactivity of sedimentary microalgal lipids in bioturbated Mediterranean coastal sediments. Mar. Chem. 81, 57-69.

Grossmann, S., Reichardt, W., 1991. Impact of Arenicola marina on bacteria in intertidal sediments. Mar. Ecol. Prog. Ser. 77, 85-96.

Harvey, H.R., Eglinton, G., O’Hara, S.C.M., Corner, E.D.S., 1987. Biotransformation and assimilation of dietary lipids by Calanus feeding on a dinoflagellate. Geochim. Cosmochim. Acta 51, 3031-3040.

Harwood, J.L., Russell, N.J., 1984. Lipids in Plants and Microbes. George Allen and Unwin, London.

Hastie, T., Tibshirani, R., Friedman, J., 2001. The Elements of Statistical Learning: Data Mining, Inference and Prediction. Springer, New York.

Lopez, G.R., Levinton, J.S., 1987. Ecology of deposit-feeding animals in marine sediments. Quart. Rev. Biol. 62, 235-260.

Lucas, F.S., Bertru, G., Höfle, M.G., 2003. Characterization of freeliving and attached bacteria in sediments colonized by Hediste diversicolor. Aquat. Microb. Ecol. 32, 165-174.

Meziane, T., Sanabe, M.C., Tsuchiya, M., 2002. Role of fiddler crabs of a subtropical intertidal flat on the fate of sedimentary fatty acids. J. Exp. Mar. Biol. Ecol. 270, 191-201.

Müller-Navarra, D.C., Brett, M.T., Liston, A.M., Goldman, C.R., 2000. A highly unsaturated fatty acid predicts carbon transfer between primary producers and consumers. Nature 403, 74-77.

Nichols, D.S., 2003. Prokaryotes and the input of polyunsaturated fatty acids to the marine food web. FEMS Microbiol. Lett. 219, 1-7.

Plante, C.J., Shriver, A.G., 1998. Differential lysis of sedimentary bacteria by Arenicola marina L.: examination of cell wall structure and exopolymeric capsules as correlates. J. Exp. Mar. Biol. Ecol. 229, 35-52.

Plante, C.J., Stinson, S., 2003. Recolonization and cues for bacterial migration into 'mock' deposit-feeder fecal casts. Aquat. Microb. Ecol. 33, 107-115.

Plante, C.J., Wilde, S.B., 2001. Bacterial recolonization of depositfeeder egesta: in situ regrowth or immigration? Limnol. Oceanogr. 46, 1171-1181.

Plante, C.J., Wilde, S.B., 2004. Biotic disturbance, recolonization, and early succession of bacterial assemblages in intertidal sediments. Microb. Ecol. 48, 154-166.

Ranjard, L., Nazaret, S., Goubière, F., Thioulouse, J., Linet, P., Richaume, A., 2000. A soil microscale study to reveal the heterogeneity of $\mathrm{Hg}(\mathrm{II})$ impact on indigenous bacteria by quantification of adapted phenotypes and analysis of community DNA fingerprints. FEMS Microbiol. Ecol. 31, 107-115.

Retraubun, A.S.W., Dawson, M., Evans, S.M., 1996. The role of the burrow funnel in feeding processes in the lugworm Arenicola marina (L.). J. Exp. Mar. Biol. Ecol. 202, 107-118.

Riisgård, H.U., Banta, G.T., 1998. Irrigation and deposit feeding by the lugworm Arenicola marina, characteristics and secondary effects on the environment. A review of current knowledge. Vie et Milieu 48, 243-257.

Roose-Amsaleg, C.L., Garnier-Sillam, E., Harry, M., 2001. Extraction and purification of microbial DNA from soil and sediment samples. Appl. Soil Ecol. 18, 47-60.

Tsai, Y., Olson, B.H., 1991. Rapid method for direct extraction of DNA from soil and sediments. Appl. Environ. Microbiol. 57, 70-1074.

Wilde, S.B., Plante, C.J., 2002. Spatial heterogeneity of bacterial assemblages in marine sediments: the influence of deposit feeding by Balanoglossus aurantiacus. Estuar. Coast. Shelf Sci. 55, 97-107.

Yannarell, A.C., Triplett, E.W., 2004. Within- and between-lake variability in the composition of bacterioplankton communities: investigations using multiple spatial scales. Appl. Environ. Microbiol. 70, 214-223.

Yano, Y., Nakayama, A., Yoshida, K., 1997. Distribution of polyunsaturated fatty acids in bacteria present in intestines of deep-sea fish and shallow-sea poikilothermic animals. Appl. Environ. Microbiol. 63, 2572-2577. 